\title{
Hydrocarbon and Fatty Acid Composition of Cheese As Affected by the Pasture Vegetation Type
}

\author{
Milena Povolo, ${ }^{* \dagger}{ }^{\dagger}$ Valeria Pelizzola, ${ }^{\dagger}$ Giampiero Lombardi, ${ }^{\S}$ Aldo Tava, ${ }^{\ddagger}$ and Giovanna Contarini ${ }^{\dagger}$ \\ ${ }^{\dagger}$ CRA - Centro di Ricerca per le Produzioni Foraggere e Lattiero-Casearie, Via A. Lombardo 11, 26900 Lodi, Italy \\ ${ }^{\S}$ Dipartimento di Agronomia, Selvicoltura e Gestione del Territorio, Università di Torino, Via L. Da Vinci 44, 10095 Grugliasco, \\ Torino, Italy \\ ${ }^{\ddagger}$ CRA - Centro di Ricerca per le Produzioni Foraggere e Lattiero-Casearie, Viale Piacenza 29, 26900 Lodi, Italy
}

ABSTRACT: The determination of the geographical origin of dairy products is an ongoing issue. In this paper the effects of botanical diversity of two pastures on the hydrocarbon and fatty acid composition of cheese fat were studied, over 2 years of experimentation. Two areas in the Italian southwestern Alpine region, dominated by Trifolium alpinum (T) and Festuca nigrescens (F) vegetation, respectively, were chosen, and milk obtained from cows grazing on these pastures was used to produce a semihard traditional cheese. Cheese samples showed a significantly different composition of most linear hydrocarbons, odd-chain $(\mathrm{C} 15, \mathrm{C} 17$, and C17:1) and unsaturated (trans-11,cis-15-C18:2, C18:3, C20:4n-6, C20:4n-3, and 20:5n-3) fatty acids, according to pasture type. The ratio between $\mathrm{C}_{29}$ and $\mathrm{C}_{27}$ linear hydrocarbons, unlike the absolute content of the single molecules, showed a good discriminating ability between the two pastures and was little affected by the natural variability due to the climatic and environmental factors.

KEYWORDS: hydrocarbons, fatty acids, cheese, pasture

\section{INTRODUCTION}

Traceability is a key issue in particular for Protected Designation of Origin (PDO) productions. As for the dairy sector, PDO cheeses have specific characteristics and are defined according to their geographical area of production and to the cheesemaking procedures. Different approaches have been carried out to assess the origin authenticity of dairy products. ${ }^{1-9}$ Attention has mainly been focused on the identification and quantification of specific compounds, and very often terpenes have attracted the main interest as tracers of the animal's pasturefeeding diet. Terpenes have been detected and identified in dairy products for decades, and many studies have shown that milk and cheese from different productions and seasons can be differentiated. ${ }^{3,4,6-9}$ However, milk terpene content is highly influenced by vegetation, climate, and length of the grazing season. Its variability, which also derives from analytical difficulties, challenges the reliability of using terpene fingerprints for tracing the origin of dairy products. $7,9,10$

A different approach to the traceability issue takes into account the nonvolatile hydrocarbon compounds present in the neutral lipid fraction of fat. In a previous paper ${ }^{11}$ the suitability of both isoprenoid hydrocarbons and esters of isoprenoid alcohols for the discrimination between lowland and highland dairy products was shown. In particular, 1-phytene, 2-phytene, and neophytadiene seemed to be promising markers of the origin of dairy products. Hydrocarbons are minor components of the unsaponifiable fraction of edible oils and fats. Most fat matrices contain small quantities of linear, branched, saturated, unsaturated, and terpenic hydrocarbons, and studies have been carried out to characterize the hydrocarbon fraction of some foods. ${ }^{12-19}$

Moreover, many studies have been carried out on the influence of the feeding system on the fatty acid (FA) composition of milk fat, particularly with regard to the effects of different diets on the content of the unsaturated long-chain fatty acids, such as linolenic and conjugated linoleic acid. ${ }^{7,8,20-24}$ These acids are claimed to have positive effects on human health, and many studies have been carried out to naturally increase, through cow feeding, their content in milk. Fresh green forage, having higher levels of polyunsaturated fatty acids with respect to silage, allows the production of milk with a high content of polyunsaturated fatty acids. ${ }^{20,22}$ The effect of Trifolium alpinum and Festuca nigrescens on the FA composition of milk and cheese has been recently tackled by Falchero et al., ${ }^{25}$ who detected a significantly higher content of odd-chain (C15, C17, and C17:1) FAs in dairy samples deriving from T. alpinum-dominated pasture and a significantly higher content of $\alpha$-linolenic acid in those deriving from F. nigrescens-dominated pasture. That paper reported the results of the first year of experimentation of the research project "Pro-Alpe" aiming at the characterization and protection of typical dairy products through the detailed definition of the terroir of the Italian Alpine mountains.

Our research is included in the same project, but our first objective was to verify if cheese obtained from milk of cows grazing on two different types of vegetation, under the same grazing management and in the same geographical site, could be discriminated on the basis of the composition of their hydrocarbon fraction. To verify the influence of the natural sources of variability, such as environmental conditions (e.g., climate, contribution of the minor botanical species) or characteristics

Received: September 19, 2011

Revised: December 6, 2011

Accepted: December 7, 2011

Published: December 7, 2011 
of the herd, the experiment was repeated for two consecutive years.

In addition, the FA composition of cheese produced in the two years was carried out to confirm the results obtained on the samples of the first year of experimentation. ${ }^{25}$ For this purpose all of the cheese samples were analyzed by applying analytical procedures useful to detect and quantify branched and trans fatty acids, as well.

\section{MATERIALS AND METHODS}

Experimental Design. The study was conducted on a dairy farm in the Italian southwestern Alpine region (2230-2240 m asl) during the summer period of 2007 and 2008 (July 11-August 4, both years). The pasture vegetation was surveyed to map surfaces covered by two different vegetation types considered interesting for dairy production. Every year the selected areas were fenced to create four paddocks (two for adaptation and two for the experimental trial) for each treatment (Figure 1). In both years of experimentation the vegetation of paddock

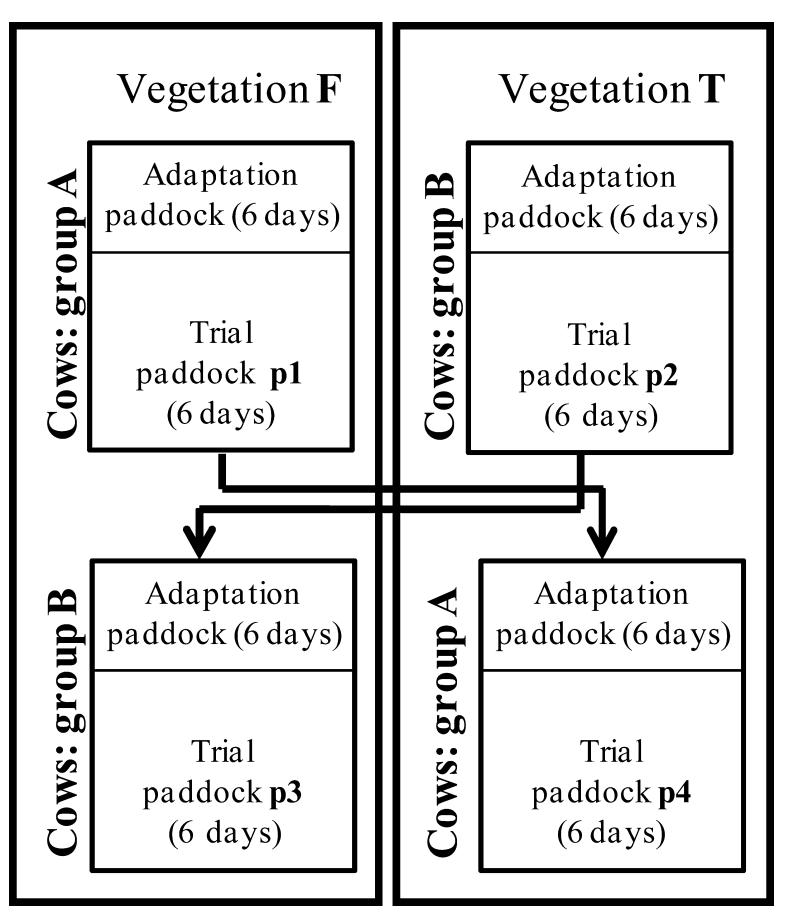

Figure 1. Experimental scheme: F, Festuca nigrescens pasture; T, Trifolium alpinum pasture.

$\mathrm{F}$ ( $\mathrm{p} 1$ and $\mathrm{p} 3$ ) had a higher abundance of $F$. nigrescens, whereas in paddock $\mathrm{T}$ ( $\mathrm{p} 2$ and $\mathrm{p} 4)$ the vegetation was dominated by T. alpinum. Details of the composition of the two pastures were reported in previous papers. ${ }^{25,26}$

During the first year 18 multiparous cows in late lactation were involved in the experiment and divided into two groups, having the same number of heads of each breed. During the second year the herd was constituted of 12 multiparous cows in late lactation and divided into two groups, having each the same number of heads. Both years the two groups were balanced according to their mean daily production $(16.4 \pm 5.0 \mathrm{~kg} / \mathrm{cow} \cdot$ day $)$. During the experimentation, the cows remained in the paddocks $24 \mathrm{~h}$ a day and received only mineral supplementation without any integration feeding. The experimental design, as reproduced in Figure 1, consisted of a $2 \times 2$ crossover design. ${ }^{27}$ The herds underwent the two treatments. Both groups first spent 6 days in the adaptation paddocks, to enable the rumen to adapt completely to the vegetation type, and then were moved to the trial paddocks for the same treatment, grazing for another 6 days (period 1 , group $\mathrm{A}=$ treatment $\mathrm{F}$; group $\mathrm{B}=$ treatment $\mathrm{T}$ ). The groups were then crossed over (period 2, group $\mathrm{A}=$ treatment $\mathrm{T}$, group $\mathrm{B}=$ treatment F), and new paddocks were exploited in the same way for another $6+6$ days.

Pasture Sampling. Every year the pasture sampling ( $T$ and $F)$ was carried out 1 week before the entrance of the animals in the trial paddocks. During this week each paddock $(\mathrm{p} 1-\mathrm{p} 4)$ was sampled twice, at the first and sixth days, and samples $(100 \mathrm{~g})$ were collected in triplicate.

Cheese Manufacture and Sampling. The cheesemaking followed the traditional steps and procedures adopted for the production of a semicooked and semihard traditional cheese, named Nostrale d'Alpe. The cows were milked twice a day at 7 a.m. and 6 p.m., in the paddocks, using a mobile milking machine. The bulk milk of the afternoon of each group was stored at $10{ }^{\circ} \mathrm{C}$ throughout the night and mixed with the bulk milk of the morning milking.

In particular, about $130 \mathrm{~L}$ of milk of each group was transferred into the vat and heated at $37^{\circ} \mathrm{C}$, and liquid calf rennet $(25 \mathrm{~mL} / 100 \mathrm{~L})$ was added. Clotting time was about $40 \mathrm{~min}$, and then the curd was first cut roughly. After $10 \mathrm{~min}$, a second cut was carried out until the curd reached the size of a grain of rice. The curd stayed under whey for a few minutes and, after whey drainage, was placed into a mold and pressed. Cheese was then removed from the mold and manually salted on the surface.

After a ripening of 60 days at $10{ }^{\circ} \mathrm{C}$ and $85 \%$ relative humidity, cheeses were sampled, and a slice of about $250 \mathrm{~g}$ was taken from each whole cheese. The samples were stored at $-20{ }^{\circ} \mathrm{C}$ until the analyses.

Twenty-four cheeses were produced each year: 12 from treatment $F$ and 12 from treatment T. A total of 48 cheeses were obtained and analyzed throughout the two years of experimentation.

Reagents. High-purity standards of squalane (99\%), squalene ( $\geq 98 \%$ ), $n$-alkanes from C11 to C34 (99\%), and methyl esters (purities ranging from 99.5 to $99.8 \%$ ) and ethyl esters (purities ranging from 98 to $99 \%$ ) of fatty acids, except for ethyl palmitate and ethyl oleate, were supplied from Sigma-Aldrich (Milan, Italy); phytane (99\%) was purchased from Ultra Scientific (Bologna, Italy).

The $n$-hexane used in the whole extraction procedure of the hydrocarbon fraction was Suprasolv solvent (Merck, Darmstadt, Germany). All other reagents were of analytical grade and purchased from Sigma-Aldrich.

Chemical Composition. Dry matter, protein, fat, and ash contents of cheese samples were determined according to AOAC (2000) methods. Dry matter (DM) content of forages was determined by drying the samples in a forced draft oven at $60{ }^{\circ} \mathrm{C}$ to constant weight.

Cheese Fat Extraction. The method applied was developed at the laboratory to perform the fat extraction without using solvents. ${ }^{11}$ Frozen cheese samples were thawed slowly at refrigerator temperature $\left(4{ }^{\circ} \mathrm{C}\right)$ and finely grated. An amount of $20 \mathrm{~g}$ of grated cheese was weighed in a $60 \mathrm{~mL}$ screw-cap glass tube and warmed in a water bath at $60{ }^{\circ} \mathrm{C}$ for $20-30 \mathrm{~min}$. Furthermore, the fat fraction was separated by centrifugation at $60{ }^{\circ} \mathrm{C}$ for $20 \mathrm{~min}$ at $1250 \mathrm{rpm}$ (Gerber Instruments AG, Effretikon, Switzerland) and transferred into a glass vial.

Hydrocarbon Fraction Analysis. Cheese Samples. The hydrocarbon fraction was separated from the whole lipid matrix as described by Povolo et al. ${ }^{11}$ and analyzed by GC-MS on a TraceGC coupled with a TraceMS Plus mass spectrometer (ThermoElectron Corp., Woburn, MA). A HP 5MS (Agilent Technologies, Palo Alto, CA) capillary column ( $30 \mathrm{~m}$ length, $0.32 \mathrm{~mm}$ i.d., $0.25 \mu \mathrm{m}$ film thickness) was used. On-column injection $(1 \mu \mathrm{L})$ was adopted, and helium was used as carrier gas at a flow rate of $1.5 \mathrm{~mL} \mathrm{~min} \mathrm{mi}^{-1}$. The oven temperature was held at $60^{\circ} \mathrm{C}$ for $3 \mathrm{~min}$, programmed to $280^{\circ} \mathrm{C}$ at a rate of $10{ }^{\circ} \mathrm{C} \mathrm{min}{ }^{-1}$, held at $280{ }^{\circ} \mathrm{C}$ for $1 \mathrm{~min}$, programmed to $320^{\circ} \mathrm{C}$ at a rate of $3{ }^{\circ} \mathrm{C} \mathrm{min}^{-1}$, and held at $320{ }^{\circ} \mathrm{C}$ for $20 \mathrm{~min}$. The interface was held at $320{ }^{\circ} \mathrm{C}$ and the MS source at $250{ }^{\circ} \mathrm{C}$. Acquisition was performed in EI mode $(70 \mathrm{eV})$ by 1.0 scans s$^{-1}$, and the mass range used was $35-300 \mathrm{~m} / \mathrm{z}^{-1}$ from 5 to $18 \mathrm{~min}, 35-470 \mathrm{~m} / \mathrm{z}^{-1}$ from 18 to $28 \mathrm{~min}$, and $35-600 \mathrm{~m} / \mathrm{z}^{-1}$ from 28 to $60 \mathrm{~min}$.

Identification of the compounds was made by using the NIST library (2001), the MS data of literature, the injection of authentic 
Table 1. Mean Values and Standard Deviations of the Main Constituents (Percent Weight) of Cheese Samples Produced from Milk Deriving from the Two Vegetation Types (F. nigrescens; T. alpinum, T) in Two Different Years ${ }^{a}$

\begin{tabular}{|c|c|c|c|c|c|}
\hline & \multicolumn{2}{|c|}{ vegetation type } & \multicolumn{2}{|c|}{ year } & \\
\hline & $\mathrm{F}$ & $\mathrm{T}$ & 1 & 2 & \\
\hline dry matter & $62.39 \pm 3.09$ & $62.60 \pm 3.28$ & $64.81 \pm 2.18$ & $60.19 \pm 2.12$ & $* *$ \\
\hline fat & $31.27 \pm 2.11$ & $32.19 \pm 2.29$ & $31.90 \pm 2.35$ & $31.57 \pm 2.13$ & \\
\hline protein & $25.99 \pm 1.95$ & $25.38 \pm 1.87$ & $26.71 \pm 1.42$ & $24.65 \pm 1.80$ & $* *$ \\
\hline ash & $3.93 \pm 0.58$ & $3.86 \pm 0.47$ & $4.17 \pm 0.36$ & $3.62 \pm 0.52$ & $* *$ \\
\hline
\end{tabular}

standards (when available), and the comparison of the retention indices with published data. Phytyl esters were previously identified. ${ }^{11}$

The quantification of the compounds was performed by relating the peak abundance to that of squalane (internal standard), and the amount was expressed as milligrams per kilogram of fat.

Pasture Samples. One hundred grams of fresh sample was added to $1.2 \mathrm{mg}$ of internal standard (squalane) and extracted with three aliquots of $250 \mathrm{~mL}$ of dichloromethane. The solvent was evaporated under vacuum, and the extracted material was suspended in $10 \mathrm{~mL}$ of $n$-hexane before being loaded onto the same silica gel column applied for cheese samples. The column was eluted with $200 \mathrm{~mL}$ of $n$-hexane, and the eluate was collected, evaporated under vacuum to a small volume $(1 \mathrm{~mL})$, and analyzed by GC-MS with the same instrumentation and conditions described above for cheese samples.

Fatty Acid (FA) Composition. Fatty acids were determined as methyl esters, prepared by base-catalyzed methanolysis of glycerides using $\mathrm{KOH}$ in methanol. ${ }^{28}$

One microliter of the FAME solution was injected into a TraceGC (ThermoFisher, Rodano, Milan, Italy) gas chromatograph, equipped with a CP-Sil 88 (Varian, Santa Clara, CA) capillary column $(100 \mathrm{~m}$ length, $0.25 \mathrm{~mm}$ i.d., $0.20 \mu \mathrm{m}$ film thickness). A PTV injector in split mode (split ratio 1:100), at a constant temperature of $250{ }^{\circ} \mathrm{C}$, was used, and hydrogen $\left(0.5 \mathrm{~mL} \mathrm{~min}^{-1}\right)$ was adopted as carrier gas. The temperature program was as follows: $45^{\circ} \mathrm{C}$ for $8 \mathrm{~min}$, programmed to $173{ }^{\circ} \mathrm{C}$ at a rate of $12{ }^{\circ} \mathrm{C} \mathrm{min}{ }^{-1}$, held at $173{ }^{\circ} \mathrm{C}$ for $47 \mathrm{~min}$, programmed to $220^{\circ} \mathrm{C}$ at a rate of $4{ }^{\circ} \mathrm{C} \mathrm{min}{ }^{-1}$, and held at $220^{\circ} \mathrm{C}$ for $20 \mathrm{~min}$; a flame ionization detector (FID) was used, maintained at $250^{\circ} \mathrm{C}$.

The gas chromatographic response of short-chain fatty acids (C4-C10) was determined by preparing standard solutions of pure methyl esters (Sigma Chemical Co., St. Louis, MO) (when available) and injecting them by adopting the same instrumental conditions. Individual fatty acid methyl esters were identified by comparison to the standard mixture of Supelco 37 Component FAME Mix (Supelco, Bellefonte PA) and of CLA isomers (Sigma-Aldrich Co., St. Louis, MO). The identification of isomers of C18:1 was based on commercial standard mixtures (Supelco) and published isomeric profiles. ${ }^{29}$

Statistical Analysis. The evaluation of the effect of the different pasture and year was calculated by the analysis of variance (ANOVA). Multivariate analysis (principal component analysis (PCA)) was also applied to explore the data according to pasture type. Both statistical procedures were performed by using the XLSTAT 7.5 package (Addinsoft, France).

\section{RESULTS AND DISCUSSION}

The results for the main constituents of cheese samples are reported in Table 1. Differences statistically significant were detected for dry matter, protein, and ash contents, but only according to the year of production. The composition varied within the range usually observed for this type of cheese, which is produced in a artisanal way by a local cheesemaker, using a small amount of bulk milk.

Hydrocarbon Composition. Figure 2 shows the GC-MS chromatogram of the nonvolatile hydrocarbon fraction of a $\mathrm{T}$ (T. alpinum) cheese sample separated from the whole lipid matrix by liquid column chromatography. Among all of the compounds detected, linear and isoprenoid hydrocarbons and phytyl esters were taken into account, because in a preliminary work they had shown interesting correlations with the feeding. ${ }^{11}$

Isoprenoid hydrocarbons are plant secondary metabolites, biosynthetically formed by condensation of isoprene units. Squalene, as well as phytol derivatives, such as 1-phytene, 2phytene, phytane, and neophytadiene, are the main components of this class of compounds in milk fat. ${ }^{17,18}$ Phytenes are metabolically derived from phytol, present in ingested pastures as a part of the chlorophyll molecule, by the action of the microorganisms in rumen liquor. Phytol can be either dehydrated to neophytadiene, which is transformed to 1-phytene by hydrogenation, or directly hydrogenated to dihydrophytol, which can also originate 1-phytene via dehydratation. ${ }^{30}$ Moreover, Urbach et al. ${ }^{18}$ hypothesized that 1-phytene could be produced from neophytadiene present in pasture grass, further hydrogenated in the rumen, and then transferred into milk.

Linear-chain saturated hydrocarbons are plant secondary metabolites and reported to be important constituents of cuticular waxes. They are present as mixtures with chain lengths ranging from 21 to 37 carbon atoms, and they are mostly represented by odd-numbered homologues. In several pasture species the predominant alkanes were reported to be nonacosane $\left(C_{29}\right)$, hentriacontane $\left(C_{31}\right)$, and tritriacontane $\left(\mathrm{C}_{33}\right){ }^{31}$ n-Alkanes, as well as all other long-chain aliphatic compounds present in plant cuticular waxes, originate from a series of metabolic steps belonging to the acetyl coenzyme A biosynthetic pathway. Once very long chain fatty acids are formed, they can undergo further reductive reactions, transforming them into sets of different compounds such as aldehydes, alcohols, and finally $n$-alkanes after the loss of one carbon atom. ${ }^{32}$ The presence of these compounds in plants, as well as their function and regulation, seems to be related to protection mechanisms from environmental factors, such as prevention of water loss or of thermal or UV-related stress; perhaps it is significant that they were detected at relevant concentrations in plants growing at high altitude, ${ }^{33}$ where environmental conditions are rather harsh.

The occurrence of linear-chain alkanes in bovine and swine tissues has been associated with the vegetables consumed by animals as a part of their diet. ${ }^{13-15,34,35}$ The $n$-alkanes, being inert throughout the digestive tract, are commonly used as markers for the estimation of intake, digestibility, and diet composition in grazing animals. ${ }^{36,37}$

As for the fatty acid phytyl esters, as reported in our previous paper, ${ }^{11}$ two reasonable hypotheses can be formulated: direct transfer from grass, because they had been detected in vegetable matrices, and/or endogenous (rumen or mammary cells) esterification product between fatty acids and free (E)-phytol, which is the main isomer naturally occurring in the chlorophyll molecule. 


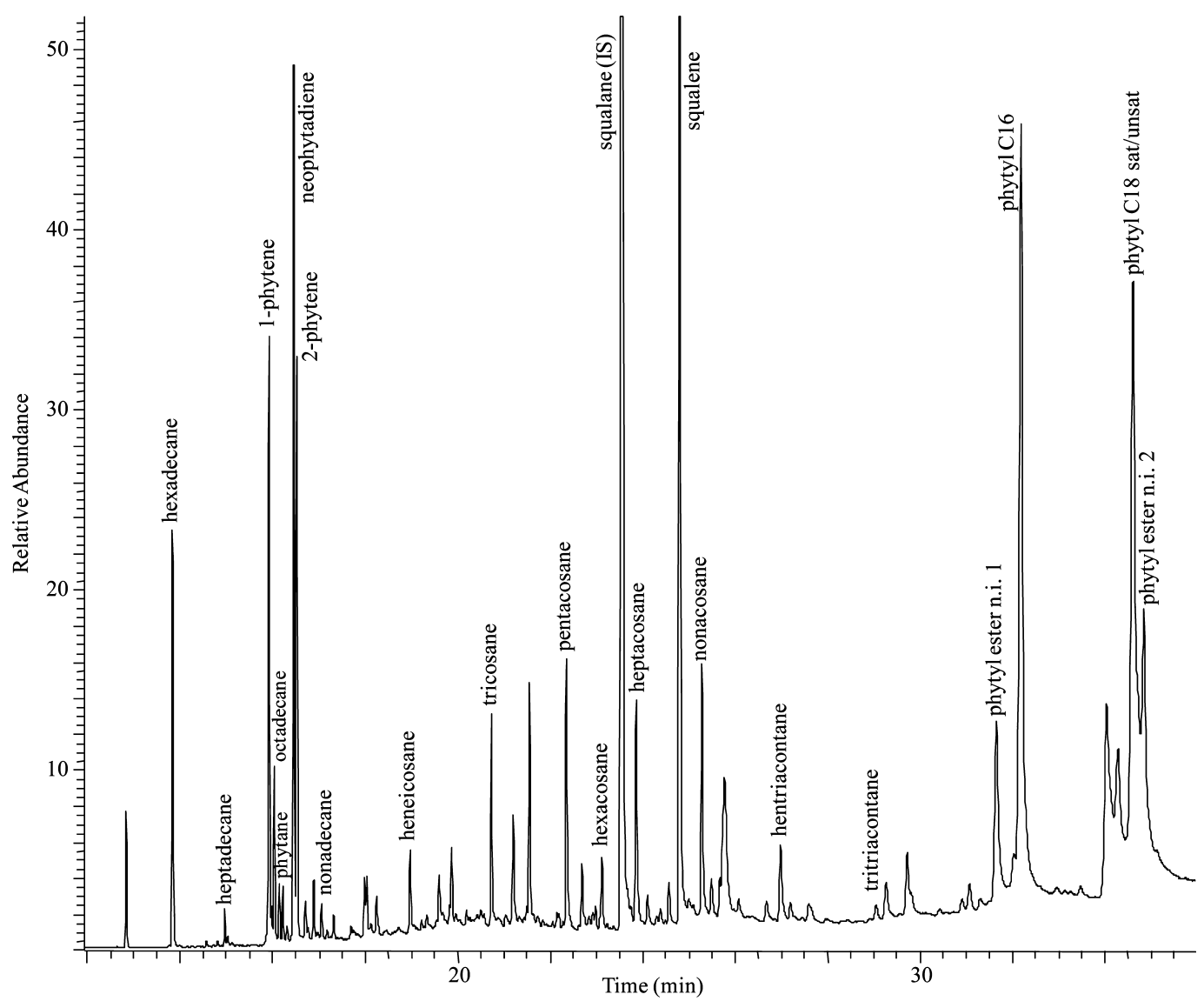

Figure 2. GC-MS profile of the nonvolatile hydrocarbon fraction of a T. alpinum cheese sample.

Before evaluation of the effect of the pastures, the total content of phytenes was calculated (1-phytene +2 -phytene + neophytadiene), to confirm the effectiveness of this index, developed by Povolo et al., ${ }^{11}$ for the distinction of dairy products deriving from milk of cows grazing on mountain pasture from those deriving from cows fed under intensive breeding systems in plain regions. The range of the values obtained on all the samples, independent of the type of pasture, varied between 20 and $80 \mathrm{mg} \mathrm{kg}^{-1}$ of fat and showed to be always higher than the values previously obtained ${ }^{11}$ for dairy samples originating from plain regions (2.5-11.1 mg kg-1 of fat), thus confirming the discriminating power of this index.

As expected, due to the lack of significant differences for 1-phytene and 2-phytene between the $\mathrm{F}$ and $\mathrm{T}$ samples, the total content of phytenes did not show any discriminating ability with respect to the samples deriving from the two different pastures (Table 2).

Together with phytenes, most of the molecules showed significant differences according to the year of experimentation; this behavior can be explained by the different climatic conditions occurring during the two years, which are responsible for the different growths of the grass and consequently for the biosyntheses of the secondary metabolites. Other compounds were statistically different according to vegetation type, but they also showed a statistically significant difference on the basis of the year. Only a few compounds, belonging to the class of $n$ alkanes, seemed less influenced by the year. In particular, hexadecane $\left(\mathrm{C}_{16}\right)$, nonacosane $\left(\mathrm{C}_{29}\right)$, and hentriacontane $\left(\mathrm{C}_{31}\right)$ showed significant differences only with respect to the type of pastoral vegetation, even though it may not be excluded that their low concentration could have masked the effect of the year.

With the aim of finding one or more parameters able to discriminate the different pastures and not, or less, influenced by the different years of sampling, some ratios between the compounds were calculated and tested. The ratio $\mathrm{C}_{29} / \mathrm{C}_{27}$ provided the most effective discrimination between the two groups of cheese. Cheese samples deriving from vegetation $\mathrm{T}$ showed a higher content of nonacosane than of heptacosane $\left(\mathrm{C}_{29} / \mathrm{C}_{27}=1.8 \pm 0.5\right)$, whereas lower values of this ratio were observed for the samples belonging to the group of vegetation $\mathrm{F}(1.0 \pm 0.2)$. To better display the differences obtained for the two categories of cheeses, the values of $\mathrm{C}_{29} / \mathrm{C}_{27}$, obtained for each sample, were subtracted from the overall mean of the values of the ratio (1.4), and results are drawn in a bar chart (Figure 3). With the exception of six samples, all of the samples deriving from pasture $\mathrm{F}$ showed positive values, whereas those deriving from pasture $\mathrm{T}$ showed negative ones. The real influence of the pasture on the hydrocarbon composition of cheese was then verified by analyzing the hydrocarbon fraction of $\mathrm{T}$ and $\mathrm{F}$ pasture samples.

The main components detected in the fresh pastures included linear odd-chain alkanes together with two isoprenoid compounds, named neophytadiene and squalene (Table 3). All of the compounds, except for neophytadiene, squalene, and tritriacontane $\left(\mathrm{C}_{33}\right)$, were influenced by the year, and three constituents $\left(\mathrm{C}_{25}, \mathrm{C}_{27}\right.$, and $\left.\mathrm{C}_{33}\right)$ were highly affected $(p<0.01)$ by the vegetation type. By comparison of the profile of oddchain alkanes of pasture with that of cheese, important differences were observed (Tables 2 and 3). Independent of 
Table 2. Mean Values (Milligrams per Kilogram of Fat) and Standard Deviations of the Main Nonvolatile Hydrocarbons Detected in Cheese Samples Produced from Milk Deriving from the Two Vegetation Types (F. nigrescens, F; T. alpinum, T) in Two Different Years ${ }^{a}$

\begin{tabular}{|c|c|c|c|c|c|c|c|}
\hline \multirow[b]{2}{*}{ compound } & \multirow[b]{2}{*}{ identification method $^{b}$} & \multicolumn{2}{|c|}{ vegetation type } & & \multicolumn{2}{|c|}{ year } & \\
\hline & & $\mathrm{F}$ & $\mathrm{T}$ & & 1 & 2 & \\
\hline hexadecane $\left(\mathrm{C}_{16}\right)$ & MSa & $0.6 \pm 0.46$ & $0.4 \pm 0.20$ & $*$ & $0.4 \pm 0.22$ & $0.6 \pm 0.47$ & \\
\hline heptadecane $\left(\mathrm{C}_{17}\right)$ & MSa & $1.1 \pm 0.60$ & $1.1 \pm 0.52$ & & $1.4 \pm 0.55$ & $0.7 \pm 0.18$ & $* *$ \\
\hline 1-phytene & $\mathrm{MSr} / \mathrm{PI}$ & $21.2 \pm 10.71$ & $22.7 \pm 12.66$ & & $31.7 \pm 7.86$ & $12.2 \pm 3.90$ & $* *$ \\
\hline octadecane $\left(\mathrm{C}_{18}\right)$ & MSa & $4.1 \pm 1.64$ & $3.5 \pm 1.59$ & $*$ & $5.1 \pm 1.17$ & $2.5 \pm 0.60$ & $* *$ \\
\hline phytane & MSa & $1.5 \pm 0.84$ & $1.4 \pm 0.56$ & & $2 \pm 0.59$ & $0.9 \pm 0.20$ & $* *$ \\
\hline neophytadiene & $\mathrm{MSr} / \mathrm{PI}$ & $8.2 \pm 2.48$ & $8.1 \pm 1.84$ & & $7.2 \pm 1.69$ & $9.1 \pm 2.22$ & $* *$ \\
\hline 2-phytene & $\mathrm{MSr} / \mathrm{PI}$ & $15.6 \pm 6.74$ & $16.1 \pm 5.61$ & & $21.1 \pm 4.20$ & $10.6 \pm 1.56$ & $* *$ \\
\hline nonadecane $\left(\mathrm{C}_{19}\right)$ & MSa & $0.6 \pm 0.47$ & $0.5 \pm 0.28$ & & $0.7 \pm 0.43$ & $0.4 \pm 0.30$ & $*$ \\
\hline heneicosane $\left(\mathrm{C}_{21}\right)$ & MSa & $2.3 \pm 2.15$ & $3.2 \pm 3.82$ & & $4.2 \pm 3.90$ & $1.4 \pm 0.55$ & $* *$ \\
\hline tricosane $\left(\mathrm{C}_{23}\right)$ & MSa & $7.4 \pm 5.24$ & $4.9 \pm 2.79$ & $* *$ & $9.3 \pm 4.17$ & $3.0 \pm 0.80$ & $* *$ \\
\hline pentacosane $\left(\mathrm{C}_{25}\right)$ & MSa & $8.3 \pm 3.71$ & $12.5 \pm 8.70$ & $* *$ & $16.2 \pm 5.32$ & $4.6 \pm 1.01$ & $* *$ \\
\hline hexacosane $\left(\mathrm{C}_{26}\right)$ & $\mathrm{MSa}$ & $1.5 \pm 1.27$ & $11.3 \pm 9.58$ & $* *$ & $10.6 \pm 10.28$ & $2.2 \pm 1.11$ & $* *$ \\
\hline heptacosane $\left(\mathrm{C}_{27}\right)$ & MSa & $7.3 \pm 2.74$ & $6.0 \pm 1.82$ & $*$ & $7.4 \pm 2.89$ & $5.9 \pm 1.52$ & $*$ \\
\hline squalene & MSa & $57.7 \pm 37.30$ & $62.7 \pm 34.35$ & & $92.5 \pm 19.13$ & $27.9 \pm 6.70$ & $* *$ \\
\hline nonacosane $\left(\mathrm{C}_{29}\right)$ & MSa & $7.5 \pm 3.65$ & $10.2 \pm 2.69$ & $* *$ & $9.3 \pm 3.82$ & $8.4 \pm 3.05$ & \\
\hline hentriacontane $\left(\mathrm{C}_{31}\right)$ & MSa & $3.0 \pm 1.05$ & $3.5 \pm 1.03$ & $*$ & $3.1 \pm 1.10$ & $3.4 \pm 1.03$ & \\
\hline tritriacontane $\left(\mathrm{C}_{33}\right)$ & MSa & $1.0 \pm 0.33$ & $0.9 \pm 0.33$ & & $0.9 \pm 0.31$ & $1.0 \pm 0.35$ & \\
\hline phytyl ester n.i. $1^{c}$ & & $9.1 \pm 2.90$ & $8.4 \pm 2.69$ & & $8.7 \pm 2.36$ & $8.7 \pm 3.21$ & \\
\hline phytyl C16 & MSa & $41.2 \pm 14.45$ & $27.6 \pm 8.61$ & $* *$ & $41.3 \pm 15.68$ & $27.4 \pm 5.77$ & $* *$ \\
\hline phytyl C18 sat/unsat $^{d}$ & MSa & $24.4 \pm 7.67$ & $18.0 \pm 5.89$ & $* *$ & $25.1 \pm 8.20$ & $17.3 \pm 4.11$ & $* *$ \\
\hline phytyl ester n.i. $2^{c}$ & & $6.5 \pm 2.55$ & $4.6 \pm 2.29$ & $* *$ & $6.8 \pm 2.95$ & $4.2 \pm 1.06$ & $* *$ \\
\hline$\Sigma$ phytenes $^{e}$ & & $45.0 \pm 16.54$ & $46.9 \pm 17.68$ & & $60.0 \pm 12.02$ & $31.85 \pm 5.51$ & $* *$ \\
\hline $\mathrm{C}_{29} / \mathrm{C}_{27}$ & & $1.0 \pm 0.22$ & $1.8 \pm 0.50$ & $* *$ & $1.4 \pm 0.70$ & $1.4 \pm 0.38$ & \\
\hline
\end{tabular}

${ }^{a}$ Significant difference: *, $p<0.05 ; * *, p<0.01 .{ }^{b}$ Confirmation of the identification: MSa, mass spectra of authentic compounds (authentic compounds had the same retention indices as the molecules detected in the samples); MSr, comparison with mass spectra reported in the literature; ${ }^{18} \mathrm{PI}$, published indices, comparison of KI calculated with published indexes. ${ }^{47}{ }^{c}$ See Figure $1 .{ }^{d}$ Saturated/unsaturated. ${ }^{e}$ Sum of 1 -phytene +2 -phytene + neophytadiene.

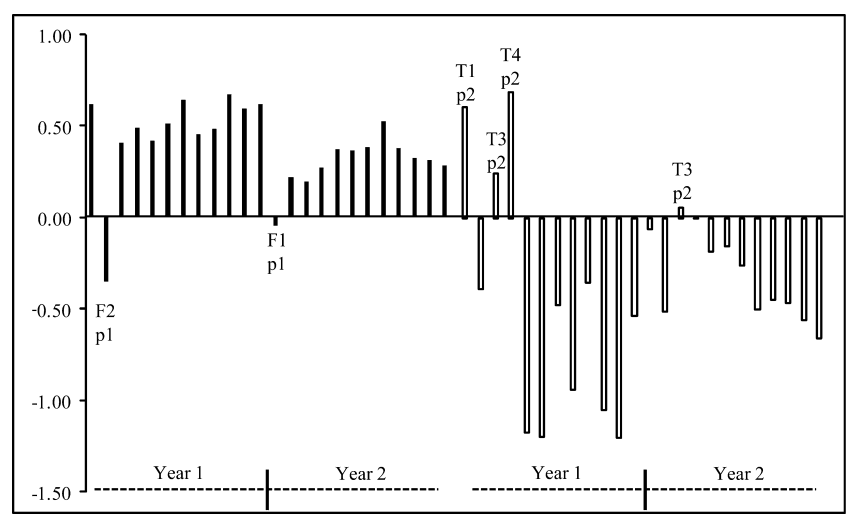

Figure 3. Ratio between the amount of $\mathrm{C}_{29}$ and $\mathrm{C}_{27}$ in cheese samples, expressed as $1.4-\mathrm{C}_{29} / \mathrm{C}_{27}$ : (black bars) F. nigrescens type (F); (white bars) T. alpinum type (T). p1-p4 identify the experimental paddocks indicated in Figure 1.

the type of pasture, $\mathrm{C}_{29}, \mathrm{C}_{31}$, and $\mathrm{C}_{33}$ were the most abundant in pasture samples, whereas $C_{25}, C_{27}$, and $C_{29}$ were the most concentrated in cheese samples. A reasonable explanation of this behavior can be derived from the results of the studies aiming to evaluate the composition, intake, and digestibility of the diet of herbivores. ${ }^{31,37,38}$ These studies are based on the determination of the concentrations of $n$-alkanes in feces, because the wax components of the different plant species have a different $n$-alkane quali-quantitative composition. An assumption inherent in this procedure is that $n$-alkanes are fully recovered in feces. However, the studies in this field clearly showed that fecal recovery was incomplete and progressively declined as carbon-chain length decreased. Dove and Mayes ${ }^{39}$ established that this incomplete recovery was due to adsorption from the small intestine. The lowest proportion of $\mathrm{C}_{31}$ and $\mathrm{C}_{33}$ on the profile of $n$-alkanes in cheese samples, in comparison to the highest values of these molecules in the two pastures, demonstrated, according to the literature, that the adsorption of long-chain hydrocarbons $\left(\mathrm{C}_{31}\right.$ and $\left.\mathrm{C}_{33}\right)$ in the small intestine, and its corresponding transfer to milk, was very low, and it increased when the number of carbon atoms decreased.

The ratio $\mathrm{C}_{29} / \mathrm{C}_{27}$ was then calculated on $\mathrm{F}$ and $\mathrm{T}$ pasture samples and provided a significant difference $(p<0.01)$ only with respect to the pasture type. The results were processed like those of cheese samples; that is, they were subtracted from the overall mean value (3.6) and drawn in a bar chart (Figure 4). Both $\mathrm{F}$ and $\mathrm{T}$ pastures showed the same positive and negative behaviors as $\mathrm{F}$ and $\mathrm{T}$ cheese samples with three exceptions. The detailed observation of the samples that in both matrices provided values in contrast with their own category, or very close to zero, allowed the detection of interesting correspondences. Cheese sample F1p1 (second year) derived from the first collection of milk of cows grazing pasture $F$ in paddock 1 , and pasture sample F2p1was collected in the same paddock 2 days before the entrance of the animals. Cheese samples T1p2, $\mathrm{T} 3 \mathrm{p} 2$, and T4p2 (first year) derived from milk of cows grazing pasture $\mathrm{T}$ in paddock 2 that gave an outlier result at the first sampling (T1p2) and a value close to zero at the second sampling (T2p2). The same correspondence was observed for 
Table 3. Mean Values (Milligrams per Kilogram DM) and Standard Deviations of the Main Nonvolatile Hydrocarbons Detected in the Two Vegetation Types (F. nigrescens, F; T. alpinum, T) in Two Different Years ${ }^{a}$

\begin{tabular}{|c|c|c|c|c|c|c|c|}
\hline \multirow[b]{2}{*}{ compound } & \multirow[b]{2}{*}{ identification method $^{b}$} & \multicolumn{2}{|c|}{ vegetation type } & & \multicolumn{2}{|c|}{ year } & \\
\hline & & $\mathrm{F}$ & $\mathrm{T}$ & & 1 & 2 & \\
\hline neophytadiene & $\mathrm{MSr} / \mathrm{PI}$ & $11.7 \pm 6.45$ & $12.1 \pm 1.4$ & & $14.1 \pm 6.51$ & $9.7 \pm 4.12$ & \\
\hline heneicosane $\left(\mathrm{C}_{21}\right)$ & MSa & $3.0 \pm 2.50$ & $1.4 \pm 1.25$ & $*$ & $3.5 \pm 2.20$ & $0.8 \pm 0.39$ & $* *$ \\
\hline tricosane $\left(\mathrm{C}_{23}\right)$ & MSa & $12.8 \pm 8.85$ & $8.6 \pm 5.51$ & & $16.5 \pm 5.94$ & $4.9 \pm 2.39$ & $* *$ \\
\hline pentacosane $\left(\mathrm{C}_{25}\right)$ & MSa & $27.2 \pm 17.48$ & $13.6 \pm 8.29$ & $* *$ & $31.0 \pm 14.26$ & $9.8 \pm 4.34$ & $* *$ \\
\hline heptacosane $\left(\mathrm{C}_{27}\right)$ & MSa & $36.9 \pm 20.43$ & $23.9 \pm 15.86$ & $* *$ & $46.5 \pm 12.22$ & $14.4 \pm 5.44$ & $* *$ \\
\hline squalene & MSa & $18.6 \pm 10.35$ & $10.2 \pm 3.44$ & $*$ & $11.1 \pm 8.11$ & $17.7 \pm 8.24$ & \\
\hline nonacosane $\left(\mathrm{C}_{29}\right)$ & MSa & $90.5 \pm 43.23$ & $96.1 \pm 49.64$ & & $132.8 \pm 23.33$ & $53.8 \pm 15.30$ & $* *$ \\
\hline hentriacontane $\left(\mathrm{C}_{31}\right)$ & MSa & $165.1 \pm 96.99$ & $94.1 \pm 49.29$ & $*$ & $181.8 \pm 83.98$ & $77.4 \pm 37.85$ & $* *$ \\
\hline tritriacontane $\left(\mathrm{C}_{33}\right)$ & MSa & $196.6 \pm 126.93$ & $29.4 \pm 19.23$ & $* *$ & $143.7 \pm 147.17$ & $82.3 \pm 93.02$ & \\
\hline $\mathrm{C}_{29} / \mathrm{C}_{27}$ & & $2.7 \pm 0.81$ & $4.5 \pm 1.21$ & $* *$ & $3.1 \pm 1.12$ & $4.1 \pm 1.48$ & \\
\hline
\end{tabular}

${ }^{a}$ Significant difference: $*, p<0.05 ; * *, p<0.01 .{ }^{b}$ Confirmation of the identification: MSa, mass spectra of authentic compounds (authentic compounds had the same retention indices as the molecules detected in the samples); MSr, comparison with mass spectra reported in the literature; ${ }^{18} \mathrm{PI}$, published indices, comparison of KI calculated with published indexes. ${ }^{47}$

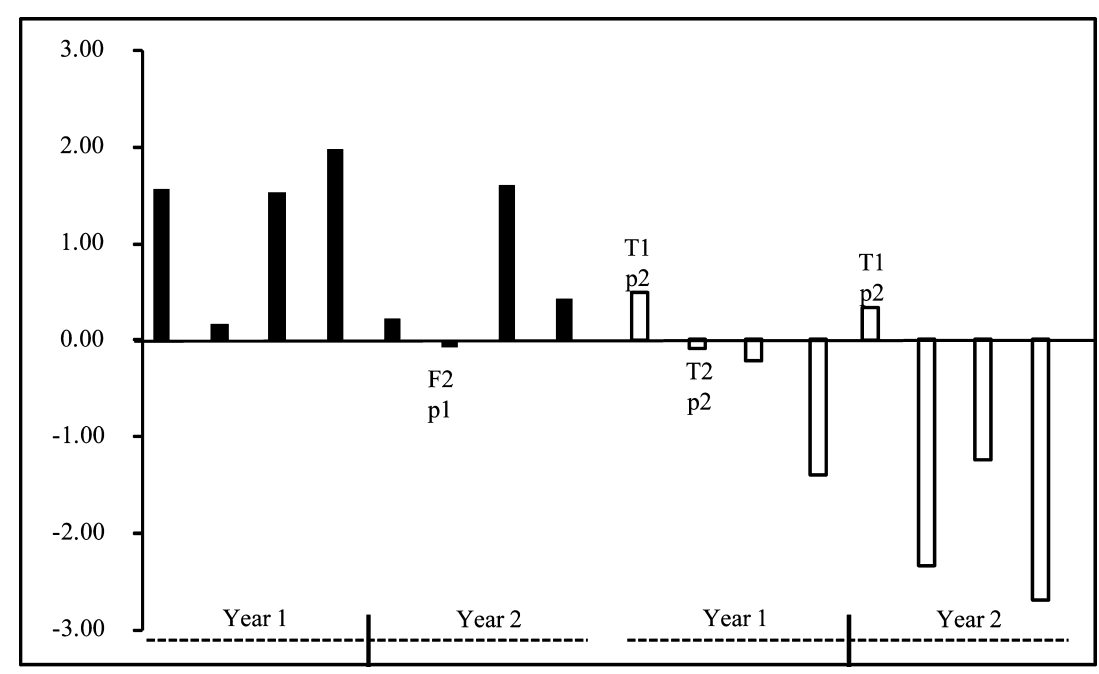

Figure 4. Ratio between the amount $\mathrm{C}_{29}$ and $\mathrm{C}_{27}$ in pasture samples, expressed as $3.6-\mathrm{C}_{29} / \mathrm{C}_{27}$ : (black bars) F. nigrescens type (F); (white bars) T. alpinum type (T). p1-p4 identify the experimental paddocks indicated in Figure 1.

cheese sample T3p2, collected in the second year of experimentation, which derived from cows grazing on paddock 2 that showed anomalous values of $\mathrm{C}_{29} / \mathrm{C}_{27}$ at its first sampling (T1p2). No direct explanation can be found for the behavior of the F2p1 cheese sample in the first year of experimentation, but a general consideration should be made when such results are discussed. A plant is a highly nonhomogeneous matrix, due to the presence of different parts (stem, leaf, flower, and seed) that are in different proportions, depending on the phenologycal stage, and give a different contribution to the chemical composition. Moreover, the pasture is a very complex natural system, including several species. Pastures $\mathrm{F}$ and $\mathrm{T}$ were defined on the basis of the species providing the most contribution (F. nigrescens and T. alpinum) and dominating during the two years, ${ }^{26}$ but their characteristics were certainly affected by the presence of other species that contributed, with their variability, to the results.

Fatty Acid Composition. Table 4 reports the results obtained from the 48 cheeses analyzed over the two years. The characteristics of the FA composition of both categories of samples were in agreement with the literature data of milk fat deriving from cows grazing in mountain pastures. ${ }^{24,40}$ The mean values of $\mathrm{F}$ and $\mathrm{T}$ groups were in satisfactory agreement with those published by Falchero et al., ${ }^{25}$ who analyzed the same cheese samples of the first year of experimentation, but applied different extraction, methylation, and GC conditions. The highest values here obtained for the short-chain fatty acids in all of the groups of samples (e.g., C4 $=4.11, \mathrm{C} 6=1.95, \mathrm{C} 8=$ 1.14 , and $\mathrm{C} 10=2.30$, for $\mathrm{F}$ samples) with respect to those previously published (Table 5 in ref 25 ) (e.g., C4 $=2.69$, C6 = $1.70, \mathrm{C} 8=1.02$, and $\mathrm{C} 10=2.10$, for $\mathrm{F}$ samples) were due to the application of the gas chromatographic correction factors, which took into account the low response of the flame ionization detector to the molecules with a low number of carbon atoms. ${ }^{41}$ The other differences were due to the highest separation ability of the GC column applied in this research that allowed a higher number of molecules to be detected and quantified, particularly branched (iso and anteiso), PUFA, and trans isomers. The data deriving from two years of experimentation (Table 4) showed that, among the fatty acids reported also by Falchero et al., ${ }^{25}$ the influence of pasture was statistically significant on a smaller number of fatty acids (C13, C15, C17, C17:1, VA, C18:1 cis 9, and C18:3). This behavior was probably due to the increased variability deriving from the presence of the results obtained during the second year of experimentation. 
Table 4. Mean Values (Grams per $100 \mathrm{~g}$ FAME) and Standard Deviations of Fatty Acids of Cheese Samples Produced from Milk Deriving from the Two Vegetation Types (F. nigrescens, F; T. alpinum, T) in Two Different Years ${ }^{a}$

\begin{tabular}{|c|c|c|c|c|c|c|}
\hline & \multicolumn{2}{|c|}{ vegetation type } & & \multicolumn{2}{|c|}{ year } & \\
\hline & $\mathrm{F}$ & $\mathrm{T}$ & & 1 & 2 & \\
\hline 4 & $4.11 \pm 0.44$ & $3.87 \pm 0.79$ & & $4.38 \pm 0.51$ & $3.60 \pm 0.53$ & $* *$ \\
\hline 6 & $1.95 \pm 0.21$ & $1.85 \pm 0.32$ & & $2.05 \pm 0.23$ & $1.75 \pm 0.24$ & $* *$ \\
\hline 8 & $1.14 \pm 0.13$ & $1.08 \pm 0.19$ & & $1.18 \pm 0.15$ & $1.04 \pm 0.15$ & $* *$ \\
\hline 10 & $2.30 \pm 0.29$ & $2.18 \pm 0.38$ & & $2.33 \pm 0.34$ & $2.15 \pm 0.33$ & \\
\hline $10: 1$ & $0.28 \pm 0.06$ & $0.27 \pm 0.05$ & & $0.30 \pm 0.05$ & $0.24 \pm 0.04$ & $* *$ \\
\hline 12 & $2.66 \pm 0.33$ & $2.55 \pm 0.44$ & & $2.76 \pm 0.38$ & $2.44 \pm 0.33$ & $* *$ \\
\hline $12: 1$ & $0.05 \pm 0.01$ & $0.04 \pm 0.01$ & & $0.05 \pm 0.01$ & $0.04 \pm 0.01$ & $* *$ \\
\hline 13 iso & $0.07 \pm 0.02$ & $0.07 \pm 0.02$ & & $0.08 \pm 0.01$ & $0.06 \pm 0.01$ & $* *$ \\
\hline 13 & $0.13 \pm 0.03$ & $0.16 \pm 0.02$ & $*$ & $0.16 \pm 0.02$ & $0.13 \pm 0.02$ & $* *$ \\
\hline 14 iso & $0.16 \pm 0.03$ & $0.15 \pm 0.03$ & & $0.17 \pm 0.02$ & $0.13 \pm 0.01$ & $* *$ \\
\hline 14 & $9.72 \pm 1.03$ & $9.57 \pm 1.01$ & & $10.14 \pm 0.88$ & $9.13 \pm 0.90$ & $* *$ \\
\hline $14: 1$ & $0.80 \pm 0.18$ & $0.8 \pm 0.15$ & & $0.93 \pm 0.12$ & $0.67 \pm 0.08$ & $* *$ \\
\hline 15 iso & $0.32 \pm 0.06$ & $0.32 \pm 0.05$ & & $0.37 \pm 0.03$ & $0.27 \pm 0.03$ & $* *$ \\
\hline 15 anteiso & $0.64 \pm 0.11$ & $0.62 \pm 0.09$ & & $0.70 \pm 0.07$ & $0.55 \pm 0.05$ & $* *$ \\
\hline 15 & $1.18 \pm 0.33$ & $1.50 \pm 0.30$ & $* *$ & $1.49 \pm 0.33$ & $1.19 \pm 0.30$ & $* *$ \\
\hline 16 iso & $0.31 \pm 0.04$ & $0.29 \pm 0.04$ & $* *$ & $0.33 \pm 0.02$ & $0.27 \pm 0.02$ & $* *$ \\
\hline 16 & $26.8 \pm 1.71$ & $26.99 \pm 1.79$ & & $25.73 \pm 1.24$ & $28.00 \pm 1.31$ & $* *$ \\
\hline cis $(7+9) 16: 1$ & $1.65 \pm 0.14$ & $1.69 \pm 0.14$ & & $1.68 \pm 0.18$ & $1.67 \pm 0.08$ & \\
\hline 17 iso & $0.56 \pm 0.05$ & $0.55 \pm 0.05$ & & $0.60 \pm 0.03$ & $0.51 \pm 0.02$ & $* *$ \\
\hline 17 anteiso & $0.47 \pm 0.05$ & $0.45 \pm 0.04$ & $*$ & $0.49 \pm 0.04$ & $0.42 \pm 0.02$ & $* *$ \\
\hline 17 & $0.76 \pm 0.16$ & $0.96 \pm 0.14$ & $* *$ & $0.93 \pm 0.15$ & $0.78 \pm 0.17$ & $* *$ \\
\hline $17: 1$ & $0.29 \pm 0.06$ & $0.38 \pm 0.06$ & $* *$ & $0.37 \pm 0.08$ & $0.30 \pm 0.06$ & $* *$ \\
\hline 18 & $9.84 \pm 1.10$ & $9.46 \pm 0.90$ & & $9.25 \pm 0.73$ & $10.03 \pm 1.11$ & $* *$ \\
\hline trans $(6+7+8) 18: 1$ & $0.27 \pm 0.03$ & $0.26 \pm 0.05$ & & $0.25 \pm 0.04$ & $0.29 \pm 0.03$ & $* *$ \\
\hline trans-9 18:1 & $0.20 \pm 0.01$ & $0.19 \pm 0.02$ & & $0.20 \pm 0.02$ & $0.19 \pm 0.02$ & \\
\hline trans-10 $18: 1$ & $0.29 \pm 0.03$ & $0.30 \pm 0.05$ & & $0.30 \pm 0.05$ & $0.29 \pm 0.03$ & \\
\hline trans-11 18:1 & $3.51 \pm 0.62$ & $3.23 \pm 0.67$ & $*$ & $2.88 \pm 0.51$ & $3.85 \pm 0.33$ & $* *$ \\
\hline trans-12 18:1 & $0.27 \pm 0.03$ & $0.26 \pm 0.03$ & & $0.27 \pm 0.03$ & $0.26 \pm 0.02$ & \\
\hline trans-16 18:1 & $0.31 \pm 0.03$ & $0.29 \pm 0.04$ & $*$ & $0.28 \pm 0.04$ & $0.32 \pm 0.03$ & $* *$ \\
\hline cis $(9+10)+\operatorname{trans}(13+14+15) 18: 1$ & $22.05 \pm 2.13$ & $23.27 \pm 1.95$ & $*$ & $22.90 \pm 2.03$ & $22.37 \pm 2.21$ & \\
\hline cis-11 18:1 & $0.62 \pm 0.07$ & $0.63 \pm 0.06$ & & $0.64 \pm 0.07$ & $0.61 \pm 0.05$ & \\
\hline cis-12 18:1 & $0.10 \pm 0.02$ & $0.10 \pm 0.02$ & & $0.12 \pm 0.01$ & $0.08 \pm 0.01$ & $* *$ \\
\hline cis-13 18:1 & $0.08 \pm 0.01$ & $0.08 \pm 0.01$ & & $0.08 \pm 0.01$ & $0.08 \pm 0.01$ & \\
\hline cis-15 18:1 & $0.20 \pm 0.02$ & $0.19 \pm 0.03$ & & $0.19 \pm 0.03$ & $0.20 \pm 0.02$ & \\
\hline$\Sigma$ cis/trans + trans $/$ cis $18: 2^{b}$ & $0.62 \pm 0.06$ & $0.59 \pm 0.06$ & $*$ & $0.64 \pm 0.06$ & $0.57 \pm 0.05$ & $* *$ \\
\hline trans-11,cis-15 18:2 & $0.55 \pm 0.07$ & $0.49 \pm 0.09$ & $* *$ & $0.48 \pm 0.08$ & $0.56 \pm 0.08$ & $* *$ \\
\hline cis-9,cis-12 18:2 (LA) & $1.57 \pm 0.19$ & $1.48 \pm 0.13$ & & $1.48 \pm 0.16$ & $1.57 \pm 0.16$ & $*$ \\
\hline 20 & $0.17 \pm 0.05$ & $0.18 \pm 0.04$ & & $0.21 \pm 0.04$ & $0.14 \pm 0.02$ & $* *$ \\
\hline $18: 3 n-6$ & $0.02 \pm 0.004$ & $0.02 \pm 0.003$ & $*$ & $0.02 \pm 0.004$ & $0.02 \pm 0.003$ & $* *$ \\
\hline cis-9,cis-12, cis-15 18:3 (ALA) & $1.24 \pm 0.14$ & $0.92 \pm 0.16$ & $* *$ & $1.03 \pm 0.21$ & $1.13 \pm 0.22$ & $*$ \\
\hline cis-9,trans-11 18:2 (CLA) ${ }^{c}$ & $1.75 \pm 0.19$ & $1.71 \pm 0.28$ & & $1.62 \pm 0.24$ & $1.84 \pm 0.18$ & $* *$ \\
\hline trans-11,cis-13 18:2 (CLA) ${ }^{d}$ & $0.13 \pm 0.02$ & $0.12 \pm 0.02$ & & $0.12 \pm 0.02$ & $0.13 \pm 0.02$ & $* *$ \\
\hline trans/trans CLA isomers & $0.04 \pm 0.006$ & $0.04 \pm 0.010$ & & $0.04 \pm 0.010$ & $0.04 \pm 0.006$ & $* *$ \\
\hline $20: 2 n-6$ & $0.03 \pm 0.011$ & $0.04 \pm 0.010$ & & $0.04 \pm 0.009$ & $0.03 \pm 0.004$ & $* *$ \\
\hline 22 & $0.08 \pm 0.034$ & $0.08 \pm 0.025$ & & $0.10 \pm 0.023$ & $0.06 \pm 0.011$ & $* *$ \\
\hline $20: 3 n-6$ & $0.05 \pm 0.007$ & $0.04 \pm 0.009$ & & $0.05 \pm 0.007$ & $0.04 \pm 0.004$ & $* *$ \\
\hline $20: 4 n-6$ (ARA) & $0.09 \pm 0.011$ & $0.08 \pm 0.013$ & $* *$ & $0.09 \pm 0.013$ & $0.08 \pm 0.008$ & $* *$ \\
\hline $20: 4 n-3$ & $0.05 \pm 0.011$ & $0.04 \pm 0.011$ & $* *$ & $0.05 \pm 0.009$ & $0.03 \pm 0.010$ & $* *$ \\
\hline $20: 5 n-3$ (EPA) & $0.06 \pm 0.013$ & $0.05 \pm 0.013$ & $* *$ & $0.06 \pm 0.010$ & $0.04 \pm 0.010$ & $* *$ \\
\hline 24 & $0.04 \pm 0.015$ & $0.05 \pm 0.017$ & & $0.06 \pm 0.015$ & $0.04 \pm 0.010$ & $* *$ \\
\hline $22: 4 n-3$ & $0.02 \pm 0.005$ & $0.01 \pm 0.006$ & $*$ & $0.01 \pm 0.004$ & $0.02 \pm 0.007$ & $* *$ \\
\hline $22: 5 n-3(\mathrm{DPA})$ & $0.08 \pm 0.017$ & $0.07 \pm 0.019$ & $*$ & $0.09 \pm 0.015$ & $0.06 \pm 0.010$ & $* *$ \\
\hline
\end{tabular}

${ }^{a}$ Significant difference: *, $p<0.05 ; * *, p<0.01 .{ }^{b}$ Sum of the peaks eluting in the region of the cis/trans and trans/cis isomers of C18:2 and C18:1-cis16. ${ }^{c}$ This peak can include trans-7,cis-9 and trans-8,cis-10, accounting for about $3 \%$ of cis-9,trans-11 CLA, according to Collomb et al. ${ }^{40} d_{\text {This peak }}$ can include some cis/cis CLA isomers, according to Kramer et al. ${ }^{43}$

Linear odd-chain fatty acids are principally derived from bacteria in the rumen, but about $10 \%$ originate from both the diet and the de novo synthesis in the mammary gland. ${ }^{42}$ The highest values of $\mathrm{C} 15, \mathrm{C} 17$, and $\mathrm{C} 17: 1$ observed in cheese 


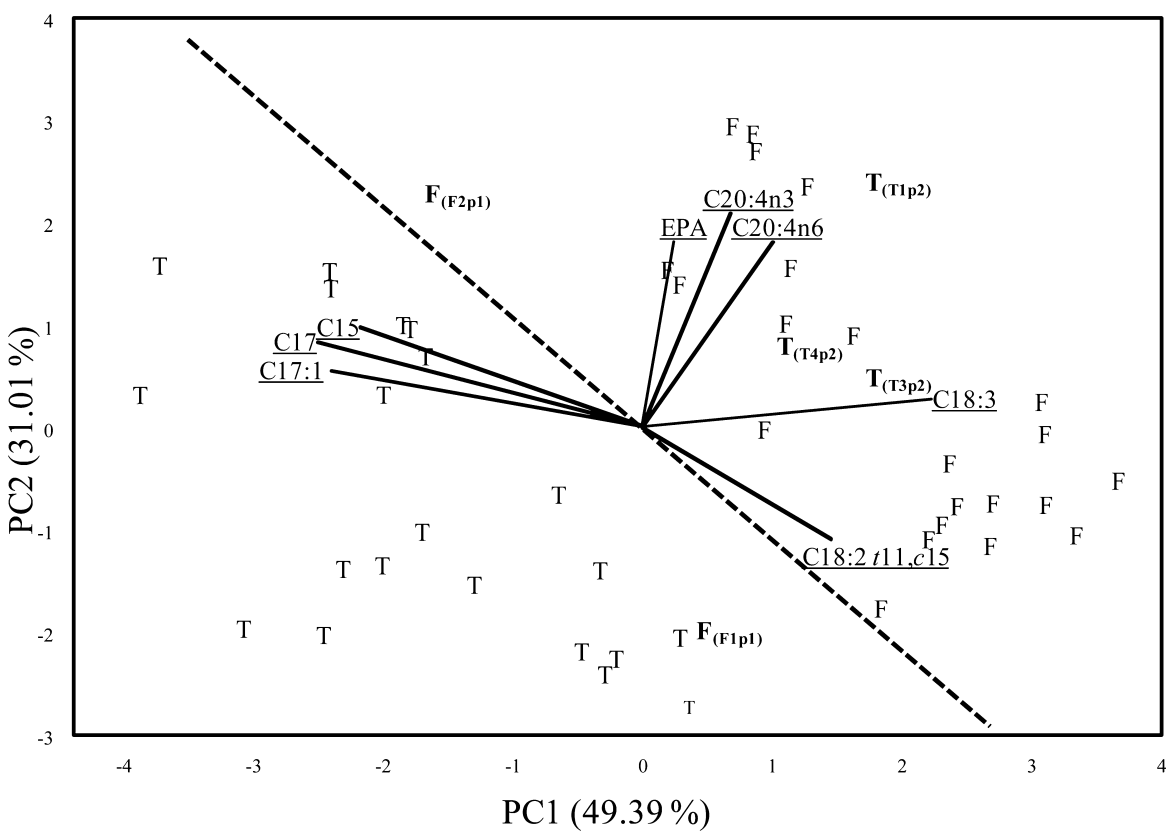

Figure 5. Biplot of the PCA of the 48 cheese samples and the variables providing differences statistically significant with $p<0.01$ (F. nigrescens, F; T. alpinum, T). The dotted line separates the space of each category.

samples of category $\mathrm{T}$ were in accordance with the highest values of the same fatty acids previously detected in $\mathrm{T}$ pasture samples. $^{25}$

The GC operative conditions applied allowed the separation of interesting isomers of both linoleic and conjugated linoleic acid. The tentative identification of these compounds was made according to the data published by different authors who used the same type of GC column and, for CLA isomers, compared the GC results with those obtained by argentation chromatography. ${ }^{29,43-45}$ The high contribution of trans-11,cis-13 18:2 to the CLA isomers eluting within the retention times of cis9,trans-11 C18:2 and trans,trans CLA was supported by the results obtained by Collomb ${ }^{40}$ on milk samples deriving from cows grazing in highlands of the Swiss Alps, approximately at the same altitude as our experimentation. The contribution of trans-11,cis-13 18:2 to the total CLA content was about $6.5 \%$ $(6.6 \pm 0.8$ in $\mathrm{F}$ samples and $6.5 \pm 0.7$ in $\mathrm{T}$ samples $)$ and this result was in accordance with Collomb et al. ${ }^{40}$ and Kraft et al., ${ }^{46}$ who found similar values in mountain milk samples (5-8\%).

At the same time, a high content of trans-11,cis-15 C18:2, the highest linoleic acid isomer found in mountain milk samples accordingly to Collomb et al., ${ }^{21,24,40}$ was detected in all samples, supporting the hypothesis that this isomer was an intermediate product in the biosynthesis of trans-11,cis-13 18:2 from $\alpha$-linoleic acid.

Among the other fatty acids detected, statistically significant differences were observed for $\mathrm{C} 16$ iso, $\mathrm{C} 17$ aiso, C18:1 trans 16 , the trans isomers of $\mathrm{C} 18: 2$, and the C20 and C22 PUFA, except for C20:3n-6. Docosahexaenoic acid was detected only in trace, in a small number of samples.

Principal component analysis (PCA) was applied to the two groups of cheeses using the FAs that showed differences statistically significant at $p<0.01$ with respect to the pasture type (C15:0, C17:0, C17:1, trans-11,cis-15 C18:2, C18:3, C20:4n-6, C20:4n-3, and EPA). The aim of the application of this multivariate procedure was to highlight, on each sample, the effect of the information included in the most discriminating variables. As expected, good separation between
$\mathrm{T}$ and $\mathrm{F}$ was obtained by taking into account the information contained in components 1 and 2, explaining $80 \%$ of the total variance (Figure 5). In addition, cheese samples F2p1, T1p2, $\mathrm{T} 3 \mathrm{p} 2$, and $\mathrm{T} 4 \mathrm{p} 2$, produced in the first year of experimentation, appeared quite far from the space of their own category and were the same samples recognized as the main outliers by the value of nonacosane/heptacosane ratio (Figure 3 ). This result strengthened that obtained by the hydrocarbon $\mathrm{C}_{29} / \mathrm{C}_{27}$ ratio and demonstrated the real link existing between the pasture and the cheese characteristics.

The hydrocarbon and fatty acid composition of the cheese produced in this experimentation reflected the characteristics of the dairy products deriving from milk of cows grazing on highland pasture, without supplementation. Moreover, the particular experimental design made it possible to detect, in cheese samples, some constituents of both hydrocarbon and fatty acid fraction that were able to discriminate the origin of milk on the basis of two different pastures defined according to their dominating species: F. nigrescens and T. alpinum.

Because the whole data set included results of two different years of experimentation, it can be reasonably concluded that the compounds detected as biomarkers were satisfactorily reliable to withstand the possible sources of natural variation, that is, climatic conditions, characteristics of the herds, and botanical composition of the minor species of vegetation, that occurred during that period. Further studies, conducted over a longer time period, will be useful to confirm the results.

This research can be an example for a methodological approach applicable to the characterization of small dairy productions, typical of narrow geographical regions, but having a great importance for territory protection and economic development.

\section{AUTHOR INFORMATION}

\section{Corresponding Author}

*Phone: +39 0371 45011. Fax: +39 0371 35579. E-mail: milena.povolo@entecra.it. 


\section{Funding}

This research was supported by interdepartmental funding MEF, MIUR, MiPAAF, and MATT within the FISR-Project Pro-Alpe "Importance of the Alpine terroir for the characterization and preservation of mountain dairy products" (Coordinator: Efisio Piano).

\section{REFERENCES}

(1) Pillonel, L.; Badertscher, R.; Casey, M.; Meyer, J.; Rossmann, A.; Schlichtherle-Cerny, H.; Tabacchi, R.; Bosset, J. O. Geographic origin of European Emmental cheese: characterization and descriptive statistics. Int. Dairy J. 2005, 15, 547-556.

(2) Engel, E.; Ferlay, A.; Cornu, A.; Chilliard, Y.; Agabriel, C.; Bielicki, G.; Martin, B. Relevance of isotopic and molecular biomarkers for the authentication of milk according to production zone and type of feeding of the cow. J. Agric. Food Chem. 2007, 55, 9099-9108.

(3) Favaro, G.; Magno, F.; Boaretto, A.; Bailoni, L.; Mantovani, R. Traceability of Asiago Mountain cheese: a rapid, low-cost analytical procedure for its identification based on solid-phase microextraction. J. Dairy Sci. 2005, 88, 6426-3434.

(4) Schlichtherle-Cerny, H.; Imhof, M.; Fernandez-Garcia, E.; Bosset, J. O. Changes in terpene composition from pasture to cheese. Mitt. Lebensm. Hyg. 2004, 95, 681-688.

(5) Bontempo, L.; Larcher, R.; Camin, F.; Hölzl, S.; Rossmann, A.; Horn, P.; Nicolini, G. Elemental and isotopic characterization of typical Italian alpine cheeses. Int. Dairy J. 2011, 21, 441-446.

(6) Povolo, M.; Contarini, G.; Mele, M.; Secchiari, P. Study on the influence of pasture on volatile fraction of ewes' dairy products by solid-phase microextraction and gas chromatography-mass spectrometry. J. Dairy Sci. 2007, 90, 556-569.

(7) De Noni, I.; Battelli, G. Terpenes and fatty acid profiles of milk fat and "Bitto" cheese as affected by transhumance of cows on different mountain pastures. Food Chem. 2008, 109, 299-309.

(8) Revello Chion, A.; Tabacco, E.; Giaccone, D.; Peiretti, P. G.; Battelli, G.; Borreani, G. Variation of fatty acid and terpene profiles in mountain milk and "Toma piemontese" cheese as affected by diet composition in different seasons. Food Chem. 2010, 121, 393-399.

(9) Tornambé, G.; Cornu, A.; Pradel, P.; Kondjoyan, N.; Carnat, A. P.; Petit, M.; Martin, B. Changes in terpene content in milk from pasture-fed cows. J. Dairy Sci. 2006, 89, 2309-2319.

(10) Fernandez, C.; Astier, C.; Rock, E.; Coulon, J.-B.; Berdague, J.-L. Characterization of milk by analysis of its terpene fractions. Int. J. Food Sci. Technol. 2003, 38, 445-451.

(11) Povolo, M.; Pelizzola, V.; Ravera, D.; Contarini, G. Significance of the non volatile minor compounds of the neutral lipid fraction as markers of the origin of dairy products. J. Agric. Food Chem. 2009, 57, 7387-7394.

(12) Bortolomeazzi, R.; Berno, P.; Pizzale, L.; Conte, L. Sesquiterpenes, alkene, and alkane hydrocarbons in virgin olive oils of different varieties and geographical origins. J. Agric. Food Chem. 2001, 49, $3278-3283$.

(13) Larick, D. K.; Hedrick, H. B.; Bailey, M. E.; Williams, J. E.; Hancock, D. L.; Garner, G. B.; Morrow, R. E. Flavor constituents of beef as influenced by forage- and grain-feeding. J. Food Sci. 1987, 52, $245-251$.

(14) Tejeda, J. F.; García, C.; Petrón, M. J.; Andrés, A. I.; Antequera, T. $n$-Alkane content of intramuscolar lipids of Iberian fresh ham from different feeding systems and crossbreeding. Meat Sci. 2001, 57, 371377.

(15) Gamero-Pasadas, A.; Viera Alcaide, I.; Rios, J. J.; Graciani Constante, E.; Vicario, I. M.; Léon-Camacho, M. Characterization and quantification of the hydrocarbons fraction of the subcutaneous fresh fat of Iberian pig by off-line combination of high performance liquid chromatography and gas chromatography. J. Chromatogr., A 2006, 1123, 82-91.

(16) Flanagan, V. P.; Ferretti, A. Hydrocarbons and polychlorinated biphenyls from the unsaponifiable fraction of anhydrous milk fat. J. Lipid Res. 1973, 14, 306-311.
(17) Flanagan, V. P.; Ferretti, A.; Schwartz, D. P.; Ruth, J. M. Characterization of two steroidal ketones and two isoprenoid alcohols in dairy products. J. Lipid Res. 1975, 16, 97-101.

(18) Urbach, G.; Stark, W. The C-20 hydrocarbons of butterfat. J. Agric. Food Chem. 1975, 23, 20-24.

(19) Cerbulis, J.; Flanagan, V. P.; Farrel, H. M. Composition of the hydrocarbon fraction of goats' milk. J. Lipid Res. 1985, 26, 1438-1443.

(20) White, S. L.; Bertrand, J. A.; Wade, M. R.; Washburn, S. P.; Green, J. T.; Jenkins, T. C. Comparison of fatty acid content of milk from Jersey and Holstein cows consuming pasture or a total mixed ration. J. Dairy Sci. 2001, 84, 2295-2301.

(21) Collomb, M.; Bütikofer, U.; Sieber, R.; Jeangros, B.; Bosset, J.-O. Composition of fatty acids in cow's milk fat produced in the lowlands, mountains and highlands of Switzerland using high-resolution gas chromatography. Int. Dairy J. 2002, 12, 649-659.

(22) Elgersma, A.; Ellen, G.; van der Horst, H.; Boer, H.; Dekker, P. R; Tamminga, S. Quick changes in milk fat composition from cows after transition from fresh grass to a silage diet. Anim. Feed Sci. Tecnol. 2004, $117,13-27$.

(23) Ellis, K. A.; Innocent, G.; Grove-White, D.; Cripps, P.; McLean, W. G.; Howard, C. V.; Mihm, M. Comparing the fatty acid composition of organic and conventional milk. J. Dairy Sci. 2006, 89, 19381950.

(24) Collomb, M.; Bisig, W.; Butikofer, U.; Sieber, R.; Bregy, M.; Etter, L. Fatty acid composition of mountain milk from Switzerland: comparison of organic and integrated farming system. Int. Dairy J. 2008, 18, 976-982.

(25) Falchero, L.; Lombardi, G.; Gorlier, A.; Lonati, M.; Odoardi, M.; Cavallero, A. Variation in fatty acid composition of milk and cheese from cows grazed on two alpine pastures. Dairy Sci. Technol. 2010, 90, $657-672$.

(26) Lombardi, G.; Cavallero, A.; Bassignana, M. Caratterizzazione e utilizzazione delle risorse pastorali: pascoli e gestione pastorale. Proceedings of the final Symposium "I terroir delle Alpi per la caratterizzazione e la difesa delle produzioni casearie d'alpeggio", Torino, Oct 19-20, 2010 (http://proalpe.entecra.it/Atti_workshop_torino.htm).

(27) Kenward, M. G.; Jones, B. Design and Analysis of Cross-over Trials, 2nd ed.; Chapman and Hall/CRC: Boca Raton, FL, 2003.

(28) ISO-IDF. Milk fat-preparation of fatty acid methyl esters; International Standard ISO 15884-IDF 182; International Dairy Federation: Brussels, Belgium, 2002.

(29) Kramer, J. K. G.; Blackadar, C. B.; Zhou, J. Evaluation of two GC columns (60-m SUPELCOWAX 10 and 100-m CP Sil 88) for analysis of milkfat with emphasis on CLA, 18:1, 18:2 and 18:3 isomers, and short- and long-chain FA. Lipids 2002, 37, 823-835.

(30) Body, D. R. Characterization of bovine rumen liquor isoprenoid hydrocarbons with reference to dietary phytol. Lipids 1977, 12, 204207.

(31) Dove, H.; Mayes, R. W. Using $n$-alkanes and other plant wax components to estimate intake, digestibility and diet composition of grazing/browsing sheep and goats. Small Rumin. Res. 2005, 59, 123139.

(32) Lacey, S.; Ljerka, K.; Reinhard, J. Sealing plant surface:cuticular wax formation by epidermial cells. Annu. Rev. Plant Biol. 2008, 59, 683-707.

(33) Pilon, J. J.; Lambers, H.; Baas, W.; Tosserams, M.; Rozema, J.; Atkin, O. K. Leaf waxes of slow-growing alpine and fast-growing lowland Poa species: inherent differences and responses to UV-B radiation. Phytochemistry 1999, 50, 571-580.

(34) Post Bettenmiller, D. Biochemistry and molecular biology of wax production in plants. Annu. Rev. Plant Physiol. Plant Mol. Biol. 1996, 47, 405-430.

(35) Tejeda, J. F.; Antequera, T.; Ruiz, J.; Cava, R.; Ventanas, J.; Garcia, C. Unsaponifiable fraction content and $n$-alkane profiles of subcutaneous fat from Iberian hams. Food Sci. Technol. Int. 1999, 5, $41-45$.

(36) Dove, H.; Mayes, R. W. The use of plant wax alkanes as marker substances in studies of the nutrition of herbivores: a review. Aust. J. Agric. Res. 1991, 42, 913-952. 
(37) Ferreira, L. M. M.; Celaya, R.; García, U.; Rodrigues, M. A. M.; Osoro, K. Differences between domestic herbivores species in alkane faecal recoveries and the accuracy of subsequent estimates of diet composition. Anim. Feed Sci. Technol. 2009, 151, 128-142.

(38) Brosh, A.; Henkin, Z.; Rothman, S. J.; Aharoni, Y.; Orlov, A.; Arieli, A. Effects of faecal $n$-alkane recovery in estimates of diet composition. J. Agric. Sci. 2003, 140, 93-100.

(39) Dove, H.; Mayes, R. W. Plant wax components: a new approach to estimating intake and diet composition in herbivores. J. Nutr. 1996, $126,13-26$.

(40) Collomb, M.; Sieber, R; Bütikofer, U. CLA isomers in milk fat from cows fed diets with high levels of unsaturated fatty acids. Lipids 2004, 39, 355-364.

(41) Ulberth, F.; Gabernig, R. G.; Schrammel, F. Flame-ionization detector response to methyl, ethyl, propyl, and butyl esters of fatty acids. J. Am. Oil Chem. Soc. 1999, 76, 263-266.

(42) Vlaeminck, B.; Fievez, V.; Cabrita, A. R. J.; Fonseca, A. J. M.; Dewhurst, R. J. Factors affecting odd- and branched-chain fatty acids in milk: a review. Anim. Feed Sci. Technol. 2006, 131, 389-417.

(43) Kramer, J. K. G.; Cruz-Hernandez, C.; Zhou, J. Conjugated linoleic acids and octadecenoic acids: analysis by GC. Eur. J. Lipid Sci. Technol. 2001, 103, 594-632.

(44) Kramer, J. K. G.; Hernandez, M.; Cruz-Hernandez, C.; Kraft, J.; Dugan, M. E. R. Combining results of two GC separations partly achieves determination of all cis and trans 16:1, 18:1, 18:2 and 18:3 except CLA isomers of milk fat as demonstrated using Ag-Ion SPE fractionation. Lipids 2008, 43, 259-273.

(45) Kramer, J. K. G.; Cruz-Hernandez, C.; Deng, Z.; Zhou, J.; Jahreis, G.; Dugan, M. E. R. Analysis of conjugated linoleic acid and trans 18:1 isomers in synthetic and animal products. Am. J. Clin. Nutr. 2004, 79 (Suppl.), 1137S-1145S.

(46) Kraft, J.; Collomb, M.; Möckela, P.; Sieberb, R.; Jahreis, G. Differences in CLA isomer distribution of cow's milk lipids. Lipids 2003, 38, 657-664.

(47) Um, K. W.; Bailey, M. E.; Clarke, A. D.; Chao, R. R. Concentration and identification of volatile compounds from heated beef fat using supercritical $\mathrm{CO}_{2}$ extraction-gas liquid chromatography/mass spectrometry. J. Agric. Food Chem. 1992, 40, 1641-1646. 